\title{
COMPARATIVE EVALUATION OF ANTIDIABETIC AND ANTIOXIDANT POTENCY OF DIFFERENT EXTRACTS OBTAINED FROM MEMECYLON SPECIES
}

\author{
TUMKUR RAMASETTY BHARATHI, HARISHCHANDRA SRIPATHY PRAKASH ${ }^{*}$
}

Department of Studies in Biotechnology, University of Mysore, Manasagangotri, Mysore 570006 India

Email: hasriprakash@gmail.com

Received: 15 Oct 2016 Revised and Accepted: 21 Dec 2016

\begin{abstract}
Objective: Memecylon species is being extensively used in traditional medicine for the treatment of skin disorders and it is proved to possess antidiabetic and anti-inflammatory properties. The present investigation was to study the effect of different solvent extracts of five Memecylon species such as M. umbellatum, M. talbotianum, M. edule, M. malabaricum and M. wightii on antidiabetic and antioxidant effects.

Methods: Plant extracts were prepared using soxhlet apparatus using different solvents such as hexane, ethyl acetate, methanol and water and obtained extracts were subjected to antidiabetic ( $\alpha$-amylase and $\alpha$-glucosidase inhibition assays) and antioxidant (2, 2-Diphenyl-2-Picryl Hydrazyl hydrate (DPPH), 2,2-Azino-bis (3-ethyl benzothiazoline-6-Sulfonic acid)diammonium salt (ABTS), Superoxide radical scavenging assay (SRSA) and reducing power assays) evaluated at different doses.

Results: Methanol extracts of all five Memecylon species exhibited effective antidiabetic and antioxidant properties among them methanol extracts of M. malabaricum and M. talbotianum have highest biological activity. For $\alpha$-amylase $\mathrm{IC}_{50}$ value for both $M$. malabaricum and M. talbotianum was found to be 100 and $130 \mu \mathrm{g} /$ reaction and $\mathrm{IC}_{50}$ value for $\alpha$-glucosidase was found to be 6.1 and $7.8 \mu \mathrm{g} /$ reaction respectively. For DPPH the IC 50 value was found to be $190 \mu \mathrm{g} /$ reaction, for ABTS 31-39 $\mu \mathrm{g} /$ reaction, for SRSA 950-1200 $\mu \mathrm{g} /$ reaction and for reducing power assay 420-490 $\mu \mathrm{g} /$ reaction respectively.
\end{abstract}

Conclusion: The results indicate that methanol extracts of M. malabaricum and M. talbotianum possess potent in vitro antidiabetic and antioxidant activities compared to other Memecylon species.

Keywords: Memecylon species, Antioxidant, Antidiabetic, Methanol extracts

(C) 2017 The Authors. Published by Innovare Academic Sciences Pvt Ltd. This is an open access article under the CC BY license (http://creativecommons.org/licenses/by/4. 0/) DOI: http://dx.doi.org/10.22159/ijpps.2017v9i2.15695

\section{INTRODUCTION}

Oxidative stress is reduced by generating antioxidants from the plant and protects the body against free radical-mediated toxicities [1]. Several plant species are screened for antioxidant activities which are known to exhibit antidiabetic activity. However, it is estimated that more than 400 plant-derived products are reported to be used for the treatment of diabetes across the globe [2]. The antidiabetic effect of some plant extracts has been proved in both human and animal models of diabetes [3].

The genus Memecylon L. (Melastomataceae) is native to Asia, Africa Madagascar and pacific islands and comprises about 300 species. In the India, the genus is mainly distributed in Western Ghats region represented by about 40 species of which 21 are endemic to peninsular India $[4,5]$. The species of this family are small trees or shrubs mainly used in the treatment of skin diseases such as herpes, stomach disorders, snakebite, wounds etc., which is mainly used in traditional medicinal system $[6,7,8]$ a few compounds have been investigated and also several pharmacological properties have been reported from the crude extracts of Memecylon species [9]. Since very few studies have thrown light on bioactive properties of Memecylon species such as $M$. wightii is very less, and their comparative analysis was also few. Therefore the present study was to determine the in vitro antidiabetic and antioxidant properties of different fractions obtained from Memecylon species such as $M$. umbellatum, M. edule, M. talbotianum, M. malabaricum and M. wightii.

\section{MATERIALS AND METHODS}

\section{Chemicals}

2,2-diphenyl-2-picryl-hydrazyl (DPPH), 2,2'-azino-bis(3-ethylbenzthiazoline-6-sulphonic acid (ABTS), nicotinamide adenine dinucleotide reduced (NADH), phenazine methosulphate (PMS), nitro blue tetrazolium (NBT), potassium ferricyanide, ascorbic acid, gallic acid, quercetin, ferrous sulfate $7 \mathrm{H}_{2} \mathrm{O}, \alpha$-amylase, $\alpha$ glucosidase, 4-nitrophenyl- $\alpha$-D-glucopyranoside, All other solvents, chemicals and reagents used were of analytical grade and obtained from reputed companies.

\section{Plant materials and preparation of extracts}

Five Memecylon species namely, M. umbellatum Burm, M. edule Roxb, M. talbotianum Brandis, M. malabaricum Clarke and M. wightii Thwaites were collected from different parts of Karanataka. Shade dried leaves of Memecylon species were powdered in an electric blender and extracted sequentially with hexane, ethyl acetate, methanol and water using soxhlet apparatus.

\section{In vitro antioxidant activity}

2, 2-Diphenyl-2-Picryl Hydrazyl hydrate (DPPH) radical scavenging activity

The DPPH free radical scavenging property of the different solvent extracts of Memecylon species was determined by the method described by Sultanova [10]. The DPPH $(300 \mu \mathrm{M})$ solution was prepared in methanol containing $100 \mu \mathrm{l}$ reaction mixture containing 5 $\mu \mathrm{l}$ of plant extract (100 to $400 \mu \mathrm{g} / \mathrm{ml}$ ) and $95 \mu \mathrm{l}$ of DPPH solution. The radical scavenging reaction was carried out at $37^{\circ} \mathrm{C}$ in the dark for 30 min and the absorbance was recorded at $517 \mathrm{~nm}$. $\mathrm{IC}_{50}$ values were evaluated which indicates the concentration of extracts required to scavenge $50 \%$ of free radicals. Positive control used was ascorbic acid.

2, 2-Azino-bis (3-ethyl benzothiazoline-6-Sulfonic acid) diammonium salt (ABTS) radical scavenging activity

The antioxidant activity measured using the ABTS method described by $\operatorname{Re}[11]$. The ABTS solution was prepared by mixing $2.45 \mathrm{mmol}$ potassium persulfate and $7 \mathrm{mmol} \mathrm{ABTS}$ and keeping in the dark for $12 \mathrm{~h}$ at room temperature. The prepared ABTS solution was diluted again with methanol to get an absorbance of $0.700 \pm 0.005$ at $734 \mathrm{~nm}$. 
Different concentrations of test samples (20 to $80 \mu \mathrm{g} / \mathrm{ml}$ ) were added to $2.95 \mathrm{ml}$ of ABTS working a solution to give a final volume of $3 \mathrm{ml}$. The absorbance was recorded after incubation at room temperature for $30 \mathrm{~min}$ at $734 \mathrm{~nm}$. Gallic acid was used as a positive control.

\section{Superoxide radical scavenging assay (SRSA)}

The superoxide scavenging capacity of the plant extract was determined by the method of Singh [12]. According to this method, different concentrations of the extract (320 to $2560 \mu \mathrm{g} / \mathrm{ml}$ ) were prepared. Different concentrations of extracts were taken, and the total volume made up to $400 \mathrm{ul}$ using phosphate buffer $(0.1 \mathrm{M} \mathrm{pH}$ 7.4) containing $1 \mathrm{ml}$ of PMS $(60 \mu \mathrm{M}), 1 \mathrm{ml}$ of NADH $(677 \mu \mathrm{M})$ and $100 \mathrm{ul}$ of NBT $(144 \mu \mathrm{M})$ in phosphate buffer $(0.1 \mathrm{M}$ PH7.4). The reaction was carried out at room temperature for 5 min including blank. The color intensity was read using the spectrophotometer at $560 \mathrm{~nm}$ (Beckman Coulter, DU 730 Life Sciences).

\section{Reducing power assay}

The reducing power assay of different extracts of Memecylon species was evaluated according to the method described by Shen [13]. Different concentrations (250 to $1000 \mu \mathrm{g} / \mathrm{ml}$ ) of the sample $(1 \mathrm{ml})$ was mixed with PBS buffer (pH 7.4, 0.02M), $1.0 \mathrm{ml}$ potassium ferricyanide $(1.0 \%, \mathrm{w} / \mathrm{v})$ and the reaction was incubated at $50{ }^{\circ} \mathrm{C}$ for $20 \mathrm{~min}$. Then the reaction was terminated by adding $1.0 \mathrm{ml}$ of tri chloroacetic acid $(10.0 \%, \mathrm{w} / \mathrm{v})$ again the solution was mixed with $0.4 \mathrm{ml}$ ferric chloride $(0.1 \%, \mathrm{w} / \mathrm{v})$ and kept for $10 \mathrm{~min}$. Different concentrations of ascorbic acid were used as a positive control. The increased absorbance of the reaction mixture indicated increased reducing power by reading the absorbance at $700 \mathrm{~nm}$.

\section{Determination of $\mathrm{IC}_{50}$ value calculation for antioxidant assay}

The concentration of the sample required for scavenging $50 \%$ of the radicals/to chelate metal ions was calculated as follows.

$$
\% \text { Inhibition }=\left[\left(\mathrm{A}_{\text {control }}-\mathrm{A}_{\text {sample }}\right) / \mathrm{A}_{\text {control }}\right] \times 100
$$

Where " $A_{\text {control" }}$ is the absorbance of control, and " $A_{\text {sample }}$ " is the absorbance of the sample. $\mathrm{IC}_{50}$ values denote the concentration of a sample required to decrease the absorbance by $50 \%$.

\section{In vitro antidiabetic activity}

\section{Inhibition of $\alpha$-amylase}

The pancreatic $\alpha$-amylase (PPA) inhibition assay was carried out in a microtitre plate based on the starch-iodine test [14]. The reaction mixture consisted of $40 \mathrm{ul}$ of $0.02 \mathrm{M}$ sodium phosphate buffer (pH 6.9, containing $6 \mathrm{mmol} \mathrm{NaCl}$ ) and leaf extract at concentrations from 80 to $240 \mu \mathrm{g} / \mathrm{ml}(\mathrm{w} / \mathrm{v})$. The reaction was initiated by addition of PPA $(0.02$ units) and soluble starch $(1 \%, \mathrm{w} / \mathrm{v})$ followed by incubation at $37^{\circ} \mathrm{C}$ for $10 \mathrm{~min}$. The reaction was stopped by addition of $1 \mathrm{M} \mathrm{HCl}(20 \mathrm{ul})$. The color change by the addition of iodine reagent $(5 \mathrm{mmol}$ Iodine and 5 mmol Potassium iodide) was read at $620 \mathrm{~nm}$ on a microplate reader (VarioSkan Flash, Thermo Fisher Scientific, Finland). To eliminate the absorbance due to only extract/ enzyme/substrate, appropriate controls were included. The enzyme activity without extracts was used for all calculations. The known PPA inhibitor, acarbose (6.5 to 32.8 $\mu \mathrm{g} / \mathrm{ml}$ ) was used as positive control.

\section{Inhibition of $\alpha$-glucosidase}

The enzyme source was $\alpha$-glucosidase dissolved at a concentration of $0.1 \mathrm{U} / \mathrm{ml}$ in $0.1 \mathrm{M}$ phosphate buffer $(\mathrm{pH} 7.0)$, containing BSA $(2 \mathrm{~g} / \mathrm{ml})$ and sodium azide $(0.2 \mathrm{~g} / \mathrm{ml})$. The substrate $1 \mathrm{mmol} p$-nitrophenyl- $\alpha$-dglucopyranoside (PNPG) (20 ul) was used. Twenty microliters of different concentration of leaf extract ( 5 to $15 \mu \mathrm{g} / \mathrm{ml}$ ) was incubated for $5 \mathrm{~min}$ with the enzyme $(50 \mathrm{ul})$ and the reaction was further continued by addition of substrate $(50 \mathrm{ul})$. The reaction was terminated $5 \mathrm{~min}$ after by the addition of $50 \mathrm{mmol}$ sodium hydroxide $(3 \mathrm{ml}$ ) and the absorbance was read at $410 \mathrm{~nm}$. To eliminate the absorbance produced by the extract/enzyme/substrate, appropriate controls were included. The enzyme activity without plant extract was used for all the calculations [15].

\section{Determination of $\mathrm{IC}_{50}$ for antidiabetic assay}

The $\mathrm{IC}_{50}$ value is the concentration of the extract, containing the enzyme inhibitor that inhibited the activity by $50 \%$. The $\%$ of inhibition was calculated as follows:

$\%$ Inhibition = EC-(ET-TC) $/$ EC

Where EC is the enzyme activity of control, ET is the enzyme activity of test, and TC is the test control.

One unit of enzyme activity is defined as the amount of enzyme required to release one micromole of product from substrate per min under the assay conditions.

\section{Statistical analysis}

Values in tables and graphs were means \pm standard deviations $(n=3)$. The $\mathrm{IC}_{50}$ values were calculated from linear regression analysis. Statistical comparisons were performed by one-way analysis of variance (ANOVA) followed by Student's t-test to determine the significant difference between samples with $95 \%$ confidence limit.

\section{RESULTS}

\section{In vitro antioxidant studies}

The DPPH, ABTS, SRSA and reducing power assay of 100-400 $\mu \mathrm{g} /$ reaction for DPPH, $20-80 \mu \mathrm{g} /$ reaction for ABTS, 320-2560 $\mu \mathrm{g} /$ reaction for SRSA and 250-1000 $\mu \mathrm{g} /$ reaction for reducing power assay was calculated, and the $\mathrm{IC}_{50}$ value was determined from the linear regression of the percent antioxidant activity against extract. The antioxidant activity for each extract was dose-dependent.

The methanol extracts of five Memecylon species showed the best DPPH, ABTS, SRSA and reducing power activity, ethyl acetate, water extracts showed moderate activity and hexane extracts showed lower antioxidant activity. The radical scavenging by methanol extract was in the range of 59.3 to $89.4 \%, 70.4$ to $98 \%, 75.5$ to $94.1 \%$ and 78 to $96 \%$ respectively. The methanol extracts of $M$. malabaricum and M. talbotianum showed highest radical scavenging activity of 89.4 and $89 \%$ in DPPH, 92 and $98 \%$ in ABTS, 94.1 and $92.9 \%$ in SRSA and 96 and $93 \%$ in reducing power assay respectively (tables 1-4).

Table 1: 2, 2-diphenyl-2-picryl hydroxyl (DPPH) radical scavenging activity of Memecylon extracts

\begin{tabular}{llll}
\hline Plant & \multicolumn{3}{l}{ \%DPPH radical scavenging activity of extracts } \\
\cline { 2 - 4 } & Hexane & Ethyl acetate & Methanol \\
\hline M. umbellatum & $33.7 \pm 0.3$ & $66.9 \pm 0.2[350]^{*}$ & $59.3 \pm 0.1[300]^{*}$ \\
M. edule & $29.8 \pm 0.4$ & $29.3 \pm 0.8$ & $50.7 \pm 0.4[280]^{*}$ \\
M. talbotianum & $26 \pm 1.2$ & $75 \pm 0.9[200]^{*}$ & $30.8 \pm 0.9$ \\
M. malabaricum & $61.8 \pm 0.3[400]^{*}$ & $83.3 \pm 0.7[190]^{*}$ & $42.1 \pm 0.1$ \\
M. wightii & $49.3 \pm 0.5$ & $54.6 \pm 0.9[350]^{*}$ & $89.4 \pm 0.3[190]^{*}$ \\
\hline
\end{tabular}

Note: Ascorbic acid was used as a reference standard with $94.7 \pm 1.5 \%$ radical scavenging activity at $400 \mu \mathrm{g} / \mathrm{reaction}$ concentration and $\mathrm{IC}_{50}$ of $436 \pm 1.2 \mu \mathrm{g}$. ${ }^{* \prime}$ Represents the $\mathrm{IC}_{50}$ value of the extract in $\mu \mathrm{g}$. Data are expressed as mean $\pm \mathrm{SD}(\mathrm{n}=3)$ 
Table 2: 2, 2-Azino-bis (3-ethyl benzothiazoline-6-Sulfonic acid) diammonium salt (ABTS) radical scavenging activity of Memecylon extracts

\begin{tabular}{|c|c|c|c|c|}
\hline \multirow[t]{2}{*}{ Plant } & \multicolumn{4}{|c|}{ \%ABTS radical scavenging activity of extracts } \\
\hline & Hexane & Ethyl acetate & Methanol & Water \\
\hline M. umbellatum & $24 \pm 1.18$ & $\begin{array}{l}56 \pm 1.2 \\
{[60]^{*}}\end{array}$ & $\begin{array}{l}89 \pm 1.2 \\
{[40]^{*}}\end{array}$ & $\begin{array}{l}50 \pm 1.1 \\
{[69]^{*}}\end{array}$ \\
\hline M. edule & $30.4 \pm 0.8$ & $\begin{array}{l}54.3 \pm 0.8 \\
{[58]^{*}}\end{array}$ & $\begin{array}{l}70.4 \pm 1.08 \\
{[45]^{*}}\end{array}$ & $\begin{array}{l}56.7 \pm 0.9 \\
{[66]^{*}}\end{array}$ \\
\hline M. talbotianum & $49 \pm 1.2$ & $\begin{array}{l}80 \pm 2.1 \\
{[39]^{*}}\end{array}$ & $\begin{array}{l}98 \pm 2.8 \\
{[31]^{*}}\end{array}$ & $\begin{array}{l}61 \pm 3 \\
{[60]^{*}}\end{array}$ \\
\hline M. malabaricum & $40.2 \pm 0.6$ & $\begin{array}{l}73.3 \pm 1.4 \\
{[42]^{*}}\end{array}$ & $\begin{array}{l}92 \pm 1.4 \\
{[39]^{*}}\end{array}$ & $\begin{array}{l}71 \pm 0.9 \\
{[53]^{*}}\end{array}$ \\
\hline M. wightii & $34.3 \pm 0.6$ & $\begin{array}{l}69 \pm 1.2 \\
{[45]^{*}}\end{array}$ & $\begin{array}{l}68.2 \pm 1.2 \\
{[43]^{*}}\end{array}$ & $\begin{array}{l}59.2 \pm 1.8 \\
{[59]^{*}}\end{array}$ \\
\hline
\end{tabular}

Note: Gallic acid was used as a reference standard with $98.7 \pm 1.5 \%$ radical scavenging activity at $80 \mu \mathrm{g} /$ reaction concentration and IC 50 of $31 \pm 0.9 \mu \mathrm{g}$. '*'Represents the $\mathrm{IC}_{50}$ value of the extract in $\mu \mathrm{g}$. Data are expressed as mean $\pm \mathrm{SD}(\mathrm{n}=3)$

Table 3: Superoxide radical scavenging activity (SRSA) of Memecylon extracts

\begin{tabular}{|c|c|c|c|c|}
\hline \multirow{2}{*}{ Plant } & \multicolumn{4}{|c|}{ \% Superoxide radical scavenging activity of extracts } \\
\hline & Hexane & Ethyl acetate & Methanol & Water \\
\hline M. umbellatum & $40.5 \pm 1.8$ & $\begin{array}{l}89.2 \pm 0.2 \\
{[1200]^{*}}\end{array}$ & $\begin{array}{l}84 \pm 1.3 \\
{[1100]^{*}}\end{array}$ & $\begin{array}{l}49.6 \pm 1.4 \\
{[2400]^{*}}\end{array}$ \\
\hline M. edule & $34.5 \pm 0.9$ & $\begin{array}{l}75.1 \pm 0.6 \\
{[1500]^{*}}\end{array}$ & $\begin{array}{l}75.5 \pm 0.9 \\
{[1440]^{*}}\end{array}$ & $\begin{array}{l}55.5 \pm 0.6 \\
{[2000]^{*}}\end{array}$ \\
\hline M. talbotianum & $36.3 \pm 1.3$ & $\begin{array}{l}50 \pm 1.2 \\
{[2130]^{*}}\end{array}$ & $\begin{array}{l}92.9 \pm 0.2 \\
{[950]^{*}}\end{array}$ & $\begin{array}{l}82 \pm 1.2 \\
{[2000]^{*}}\end{array}$ \\
\hline M. malabaricum & $42 \pm 1.2$ & $\begin{array}{l}94.1 \pm 1.2 \\
{[1200]^{*}}\end{array}$ & $\begin{array}{l}94.1 \pm 0.4 \\
{[1200]^{*}}\end{array}$ & $\begin{array}{l}84.6 \pm 1.3 \\
{[1290]^{*}}\end{array}$ \\
\hline M. wightii & $34.6 \pm 2.2$ & $\begin{array}{l}80.5 \pm 1.4 \\
{[1200]^{*}}\end{array}$ & $\begin{array}{l}84 \pm 0.6 \\
{[1200]^{*}}\end{array}$ & $\begin{array}{l}52.5 \pm 0.9 \\
{[1900]^{*}}\end{array}$ \\
\hline
\end{tabular}

Note: Gallic acid was used as a reference standard with $94.7 \pm 1.2 \%$ radical scavenging activity in $2560 \mu \mathrm{g} /$ reaction concentration and $\mathrm{IC}_{50}$ of $968 \pm 0.8 \mu \mathrm{g}$. $*$ 'Represents the IC 50 value of the extract in $\mu$ g. Data are expressed as mean $\pm S D(n=3)$

Table 4: Reducing power assay of Memecylon extracts

\begin{tabular}{|c|c|c|c|c|}
\hline \multirow[t]{2}{*}{ Plant } & \multicolumn{4}{|c|}{ \% Reducing power assay of extracts } \\
\hline & Hexane & Ethyl acetate & Methanol & Water \\
\hline M. umbellatum & $\begin{array}{l}53.4 \pm 1.2 \\
{[890]^{*}}\end{array}$ & $\begin{array}{l}69.2 \pm 0.2 \\
{[710]^{*}}\end{array}$ & $\begin{array}{l}90.2 \pm 1.2 \\
{[500]^{*}}\end{array}$ & $46.3 \pm 2.2$ \\
\hline M. edule & $\begin{array}{l}57 \pm 2.6 \\
{[890]^{*}}\end{array}$ & $\begin{array}{l}77 \pm 1.2 \\
{[800]^{*}}\end{array}$ & $\begin{array}{l}78 \pm 0.9 \\
{[530]^{*}}\end{array}$ & $\begin{array}{l}63.2 \pm 1.8 \\
{[680]^{*}}\end{array}$ \\
\hline M. talbotianum & $12.9 \pm 2.9$ & $\begin{array}{l}85 \pm 2.1 \\
{[470]^{*}}\end{array}$ & $\begin{array}{l}93 \pm 1.6 \\
{[420]^{*}}\end{array}$ & $\begin{array}{l}83.8 \pm 0.9 \\
{[580]^{*}}\end{array}$ \\
\hline M. malabaricum & $\begin{array}{l}66.1 \pm 2.2 \\
{[699]^{*}}\end{array}$ & $\begin{array}{l}96 \pm 0.9 \\
{[510]^{*}}\end{array}$ & $\begin{array}{l}96 \pm 2.1 \\
{[400]^{*}}\end{array}$ & $\begin{array}{l}86.1 \pm 2.3 \\
{[480]^{*}}\end{array}$ \\
\hline M. wightii & $48 \pm 2.4$ & $\begin{array}{l}78 \pm 0.6 \\
{[690]^{*}}\end{array}$ & $\begin{array}{l}81.2 \pm 1.3 \\
{[490]^{*}}\end{array}$ & $\begin{array}{l}76.7 \pm 1.2 \\
{[590]^{*}}\end{array}$ \\
\hline
\end{tabular}

Note: Ascorbic acid was used as a reference standard with $94.7 \pm 1.5 \%$ radical scavenging activity in $1000 \mu \mathrm{g} /$ reaction concentration and $\mathrm{IC}_{50}$ of $427.6 \pm 1.6 \mu \mathrm{g}$. ${ }^{*}{ }^{\prime}$ Represents the $\mathrm{IC}_{50}$ value of the extract in $\mu \mathrm{g}$. Data are expressed as mean $\pm \mathrm{SD}(\mathrm{n}=3)$

Table 5: Inhibition of $\alpha$-amylase enzyme by plant extracts of Memecylon species

\begin{tabular}{|c|c|c|c|c|}
\hline \multirow[t]{2}{*}{ Plant } & \multicolumn{4}{|c|}{$\%$ inhibition of $\alpha$-amylase enzyme } \\
\hline & Hexane & Ethyl acetate & Methanol & Water \\
\hline M. umbellatum & $33.8 \pm 1.4$ & $\begin{array}{l}80.3 \pm 1.2 \\
{[120]^{*}}\end{array}$ & $\begin{array}{l}94.4 \pm 1.4 \\
{[99]^{*}}\end{array}$ & $44.3 \pm 0.9$ \\
\hline M. edule & $34.3 \pm 0.9$ & $\begin{array}{l}73.3 \pm 0.6 \\
{[210]^{*}}\end{array}$ & $\begin{array}{l}88 \pm 2.2 \\
{[112]^{*}}\end{array}$ & $\begin{array}{l}66.8 \pm 2.4 \\
{[240]^{*}}\end{array}$ \\
\hline M. talbotianum & $24 \pm 0.7$ & $\begin{array}{l}91 \pm 1.9 \\
{[120]^{*}}\end{array}$ & $\begin{array}{l}94 \pm 3 \\
{[130]^{*}}\end{array}$ & $\begin{array}{l}75 \pm 0.6 \\
{[210]^{*}}\end{array}$ \\
\hline M. malabaricum & $48.1 \pm 1.2$ & $\begin{array}{l}82.3 \pm 1.8 \\
{[140]^{*}}\end{array}$ & $\begin{array}{l}94.7 \pm 1.8 \\
{[100]^{*}}\end{array}$ & $\begin{array}{l}69.8 \pm 0.6 \\
{[178]^{*}}\end{array}$ \\
\hline M. wightii & $14.4 \pm 0.8$ & $\begin{array}{l}58.2 \pm 0.9 \\
{[125]^{*}}\end{array}$ & $\begin{array}{l}88.4 \pm 1.6 \\
{[110]^{*}}\end{array}$ & $\begin{array}{l}53.3 \pm 1.2 \\
{[159]^{*}}\end{array}$ \\
\hline
\end{tabular}

Note: Acarbose was used as a reference standard with $98.2 \pm 2.4 \%$ inhibitory activity at $240 \mu \mathrm{g} / \mathrm{reaction}$ concentration and IC50 of $135 \pm 0.9 \mu \mathrm{g}$. '*'Represents the $\mathrm{IC}_{50}$ value of the extract in $\mu \mathrm{g}$. Data are expressed as mean $\pm \mathrm{SD}(\mathrm{n}=3)$ 


\section{In vitro antidiabetic studies}

\section{Inhibition of $\alpha$-amylase and $\alpha$-glucosidase activity}

Carbohydrate hydrolyzing enzymes $\alpha$-amylase and $\alpha$-glucosidase are responsible for glucose generation from the diet. $\alpha$-amylase hydrolyzes alpha-1,4-glycocidic bonds and splits up starch components into smaller oligosaccharides and disaccharides, like maltose. The $\alpha$-glucosidases hydrolyze disaccharides to monosaccharides. Inhibition of these two enzymes is important for management or control of diabetes. Methanol, ethyl acetate and water extracts of five Memecylon species have shown potent antidiabetic activity. Different concentrations of extracts ranging from 80 to $240 \mu \mathrm{g} /$ reaction were tried for $\alpha$-amylase, and 5 to 15 $\mu \mathrm{g} / \mathrm{reaction}$ were tried to check for $\alpha$-glucosidase inhibitory activity.

The methanol extracts of five Memecylon species showed the best $\alpha$ amylase and $\alpha$-glucosidase inhibition activity. The inhibition of methanol extract ranged between 88 and $94.7 \%$ for $\alpha$-amylase and 67 and $97.5 \%$ for $\alpha$-glucosidase.

The methanol extract of M. malabaricum and M. talbotianum showed the highest antidiabetic activity of $94.7 \%$ and $94 \%$ for $\alpha$-amylase and $89 \%$ and $97.5 \%$ for $\alpha$-glucosidase activity. Hexane extracts showed lower activity, ethyl acetate and water extracts showed moderate inhibition for both $\alpha$-amylase and $\alpha$-glucosidase activity (table 5 and 6 ).

Table 6: Inhibition of $\alpha$-glucosidase enzyme by plant extracts of Memecylon species

\begin{tabular}{|c|c|c|c|c|}
\hline \multirow[t]{2}{*}{ Plant } & \multicolumn{4}{|c|}{$\%$ inhibition of $\alpha$-glucosidase enzyme } \\
\hline & Hexane & Ethyl acetate & Methanol & Water \\
\hline M. umbellatum & $44.5 \pm 0.9$ & $\begin{array}{l}64 \pm 2.1 \\
{[10.9]^{*}}\end{array}$ & $\begin{array}{l}84 \pm 2.3 \\
{[8]^{*}}\end{array}$ & $\begin{array}{l}56.5 \pm 0.6 \\
{[13.3]^{*}}\end{array}$ \\
\hline M. edule & $\begin{array}{l}50.5 \pm 0.5 \\
{[12]^{*}}\end{array}$ & $\begin{array}{l}56 \pm 1.8 \\
{[8.7]^{*}}\end{array}$ & $\begin{array}{l}67 \pm 2.2 \\
{[8]^{*}}\end{array}$ & $\begin{array}{l}56 \pm 2.2 \\
{[11]^{*}}\end{array}$ \\
\hline M. talbotianum & $41.2 \pm 1.2$ & $\begin{array}{l}95 \pm 1.9 \\
{[9]^{*}}\end{array}$ & $\begin{array}{l}97.5 \pm 1.8 \\
{[6.1]^{*}}\end{array}$ & $\begin{array}{l}74 \pm 2.4 \\
{[6.2]^{*}}\end{array}$ \\
\hline M. malabaricum & $\begin{array}{l}59.5 \pm 0.2 \\
{[11]^{*}}\end{array}$ & $\begin{array}{l}90 \pm 0.6 \\
{[8.7]^{*}}\end{array}$ & $\begin{array}{l}89 \pm 1.8 \\
{[7.8]^{*}}\end{array}$ & $\begin{array}{l}74 \pm 0.9 \\
{[9]^{*}}\end{array}$ \\
\hline M. wightii & $\begin{array}{l}50.5 \pm 0.6 \\
{[13]^{*}}\end{array}$ & $\begin{array}{l}72 \pm 0.9 \\
{[13]^{*}}\end{array}$ & $\begin{array}{l}74 \pm 2.3 \\
{[11]^{*}}\end{array}$ & $\begin{array}{l}62 \pm 1.2 \\
{[14]^{*}}\end{array}$ \\
\hline
\end{tabular}

Note: Acarbose was used as a reference standard with $97.2 \pm 1.4 \%$ inhibitory activity at $15 \mu \mathrm{g} / \mathrm{reaction}$ concentration and IC50 of $9.2 \pm 0.8 \mu \mathrm{g}$. '*'Represents the IC 50 value of the extract in $\mu$ g. Data are expressed as mean \pm SD $(n=3)$

\section{DISCUSSION}

Traditional knowledge about the therapeutic potential of plants is necessary to isolate and identify biologically active products from plants [16]. Therefore isolation and identification of bioactive compounds present in a crude extract serve as the building block for the development of new type of therapeutics with new mechanisms of action [17]. Bioactive properties such as antioxidant, antiinflammatory, antimicrobial and antidiabetic are very important to identify potentials of plant sources for drug development. Hence an attempt has been made to screen Memecylon species for their medicinal value. The present study clearly demonstrated that the methanol extracts of Memecylon species have significant antioxidant property when assessed by DPPH, ABTS, Superoxide radical scavenging and reducing power assays. Antioxidant activity of Memecylon species are in the order $M$. malabaricum $>M$. talbotianum $>$. umbellatum $>M$. edule $>M$. wightii. The phytochemicals are known to play an important role in bioactivity of medicinal plants. In the quantitative phytochemical analysis, phenolic content was much more than flavonoid content [7]. The alkaloids, phenolic compounds, tannins, flavonoids have been associated with various degrees of antioxidant [18] and antidiabetic activities [19]. Therefore the antioxidant and antidiabetic effects observed in the present study might be due to the activity of some of the classes of compounds present in Memecylon species. The result of antioxidant evaluation revealed that Memecylon species could be used as a potential source of natural antioxidants. The high antioxidant properties make them useful in different areas of pharmaceutical, nutraceutical and cosmeceutical applications.

In Indian traditional medicine, many of the medicinal plants have been tested to treat diabetes [20] and their active principles have been isolated [21]. Although different classes of drugs are available to control diabetes, still it is a challenging task to bring a better molecule which is devoid of undesirable adverse effects with reference to existing drugs. Therefore the search for more effective and safer hypoglycemic agents is continuing to be an important area of active research and the efficacy of antidiabetic medicinal plants have been increasingly documented [20]. In the present study, M. malabaricum and $M$. talbotianum methanol extracts showed highest $\alpha$-amylase enzyme inhibition activity compared to acarbose and in $\alpha$-glucosidase enzyme inhibition. M. talbotianum showed highest enzyme inhibition activity, followed by M. umbellatum, M. edule and M. wightii. Rajesh [22] reported antidiabetic and anti-hyperglycemic potential of M. umbellatum for different solvent extracts like hexane, ethyl acetate and methanol. Inhibition of $\alpha$-amylase, non-enzymatic glycosylation of hemoglobin, the glucose diffusion assay and the glucose uptake by the yeast cells were used to evaluate antidiabetic potential. Methanol extracts showed higher antidiabetic potential which supports present findings.

\section{CONCLUSION}

In conclusion, the results of the present study suggest that methanol extracts of M. malabaricum and M. talbotianum have potent activity, M. umbellatum, M. edule and $M$. wightii have moderate antidiabetic and antioxidant activities. The results provide useful information on free radical scavenging and antidiabetic activity of plant materials.

\section{ACKNOWLEDGEMENT}

The authors acknowledge the UGC fellowship scheme (Or. No. DV9/192/NON-NETFS/2013-14 dated: 11-11-2013) and recognition of University of Mysore as an Institution of Excellence and financial support from the Ministry of Human Resource Development, Govt. of India through UGC under UOM/ IOE/ RESEARCH/1/2010-11, dt 22-04-2010 project.

\section{CONFLICT OF INTERESTS}

The authors declare that there is no conflict of interest.

\section{REFERENCES}

1. Raghavendra M, Madhusudhana Reddy A, Yadav PR, Raju AS Siva Kumar L. Comparative studies on the in vitro antioxidant properties of methanolic leafy extracts from six edible leafy vegetables of India. Asian J Pharma Clin Res 2013;6:96-9.

2. Bailey CJ, Day C. Traditional plant medicines as treatments for diabetes. Diabetes Care 1989;12:553-64.

3. Manisha M, Prianjali D, Jaynt L, Saroj G, Thomas PAD. Indian herbs and herbal drugs used for the treatment of diabetes. J Clin Biochem Nutr 2007;40:163-73.

4. Bharathi TR, Sampath Kumara KK, Prakash HS. Memecylon species: a review of traditional information and taxonomic description. Int J Pharm Pharm Sci 2016a;8:26-34. 
5. Bharathi TR, Shailasree S, Sampath Kumara KK, Madhusudan MC, Prakash HS. Metabolite profiling by UPLC-PDA-ESI/HDMS and antibacterial activity of Memecylon talbotianum Brandis. Pharmacogn Commun 2016b;6:225-31.

6. Prakasha HM, Krishnappa M, Krishnamurthy YL, Poornima SV. Folk medicine of NR purataluk in chikmagalur district of Karnataka. Indian J Traditional Knowledge 2010;9:55-60.

7. Bharathi TR, Nadafi R, Prakash HS. In vitro antioxidant and anti-inflammatory properties of Memecylon talbotianum Brandis. Int J Phytochem 2014;4:148-52.

8. Bharathi TR, Madhusudan MC, Chandranayaka S, Prakash HS. Antimicrobial potential of Memecylon L. species from the Western Ghats against clinical isolates of pathogenic bacteria. Res J Pharm Biol Sci 2015;6:1280-7.

9. Ramasetty BT, Shrisha Naik Bajpe, Sampath Kumara KK, Ramesh Saini, Shashibhushan NB, Ramachandra Kini, et al. Identification and genetic diversity analysis of Memecylon species using ISSR, RAPD and Gene-Based DNA barcoding tools. Elect J Biotechnol 2016c;24:1-8.

10. Sultanova N, Makhmoor T, Abilov A, Parween $Z$ Omurkamzinova VB, Choudhary MI. Antioxidant and antimicrobial activities of Tamarix ramosissima. J Ethnopharmacol 2001;78:201-5.

11. Re R, Pellegrini N, Proteggente A, Pannala A, Yang M, RiceEvans C. Antioxidant activity applying an improved ABTS radical cation decolorization assay. Free Radicals Biol Med 1999;26:1231-7.

12. Singh V, Guizani N, Essa MM, Hakkim FL, Rahman MS Comparative analysis of total phenolics, flavonoid content and antioxidant profile of different date varieties (Phoenix dactylifera L.) from Sultanate of Oman. Int Food Res J 2012;19:1063-70.

13. Shen Q, Zhang B, Xu R, Wang Y, Ding X, Li P. Antioxidant activity in vitro of the selenium contained protein from the Se-enriched Bifidobacterium animalis 01. Anaerobe 2010;16:380-6.
14. Xiao Z, Storms R, Tsang A. A quantitative starch-iodine method for measuring alpha-amylase and glucoamylase activities. Anal Biochem 2006;351:146-8.

15. Subramanian R, Asmawi MZ Sadikun A. In vitro alphaglucosidase and alpha-amylase enzyme inhibitory effects of Andrographis paniculata extract and andrographolide. Acta Biochim Polonica 2008;55:391-8.

16. Sampietro DA, Catalan CA, Vattuone MA. Isolation, identification and characterization of allelochemicals/natural products; 2009. p. 555

17. Lee MJ, Prabhu S, Meng X, Li C, Yang CS. An improved method for the determination of green and black tea polyphenols in biometrics by high-performance liquid chromatography with colorimetric array detection. Anal Biochem 2000;279:164-9.

18. Gholivand MB, Rahimi-Nasrabadi M, Batooli H, Ebrahimabadi AH. Chemical composition and antioxidant activities of the essential oil and methanol extracts of Psammogeton canescens. Food Chem Toxicol 2010;48:24-8.

19. Wang SY, Lan XY, Xiao JH, Yang JC, Kao YT, Chang ST Antiinflammatory activity of Lindera erythroderma fruits. Phytotherapy Res 2008;22:213-6.

20. Mukherjee PK, Maiti K, Mukherjee K, Houghton PJ. Leads from Indian medicinal plants with hypoglycemic potentials. J Ethnopharmacol 2006;106:1-28.

21. Grover JK, Yadav S, Vats V. Medicinal plants of India with antidiabetic potential. J Ethnopharmacol 2002;81:81-100.

22. Rajesh V, Sarthaki R, Palani R, Jayaraman P. In vitro evaluation of Memecylon umbellatum Burm. F for antihyperglycemic activity and phytochemical potential. Int J Pharm Phytopharm Res 2014;6:785-91.

\section{How to cite this article}

- Tumkur Ramasetty Bharathi, Harishchandra Sripathy Prakash. Comparative evaluation of antidiabetic and antioxidant potency of different extracts obtained from Memecylon species. Int J Pharm Pharm Sci 2017;9(2):187-191. 